\title{
A Representative Work in the Academic Context of Twentieth-Century China on the History of Sino- Foreign Scientific and Technological Exchanges: A Review of Pan Jixing's On the History of Scientific and Technological Exchange between China and Foreign Countries ${ }^{1}$
}

\section{Chen Wei 陈巍 ${ }^{2}$}

(Institute for the History of Natural Sciences, Chinese Academy of Sciences, Beijing 100190, China)

Review of Pan, Jixing 潘吉星. 2012. Zhongwai kexue jishu jiaoliushi lun 中外科学技术交流史论 (On the History of Scientific and Technological Exchange between China and Foreign Countries). Beijing: China Social Sciences Press.

$\mathrm{t}$ is widely acknowledged that Science and Civilisation in China by Joseph Needham
is characterized by frequent comparisons of scientific and technological knowledge between pre-modern China and other civilizations, and attempts to demonstrate the trans-civilization transmission of knowledge. In contrast, it is unfortunate that the twenty-six volume Zhongguo kexue jishu shi 中国科学技术史 (History of science and technology in pre-modern China), edited by Lu Jiaxi 卢嘉锡 and organized by the Institute for the History of Natural Sciences (IHNS), Chinese Academy of Sciences, lacks a special volume on Sino-foreign scientific and technological interactions. Nonetheless, another treatise, found alongside Zhongguo kexue jishu shi in the library at the IHNS, one that bears a different appearance and far exceeds the average length of the book series, can largely compensate for this omission. This is Zhongwai kexue jishu jiaoliushi lun 中外科学技术交流史论 (On the History of Scientific and Technological Exchange between China and Foreign Countries) written by Pan Jixing (1931-) and published in 2012.

1 This book review has been translated from Chinese into English by Lü Xin 吕昕 and copyedited by John Moffett.

2 Research interests: History of technology and mathematics. Email: chenwei@ihns.ac.cn 


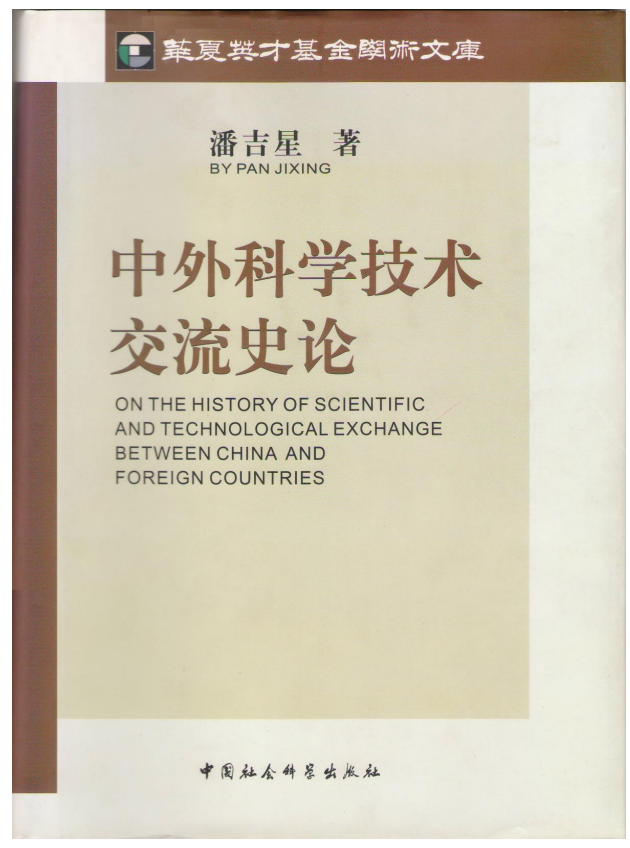

Figure 1: Zhongwai kexue jishu jiaoliushi lun 中外科学技术交流史论 (On the History of Scientific and Technological Exchange between China and Foreign Countries).

The positioning of this monograph with other volumes of Zhongguo kexue jishu shi on the same bookshelf indicates that the IHNS considers it a complement to the book series. On the one hand, this is justifiable because Pan was one of the principal participants of Zhongguo kexue jishu shi, which included his Zaozhi yu yinshua juan 造 纸与印刷卷 (Papermaking and printing) volume published in 1998. On the other hand, placing Zhongwai kexue jishu jiaoliushi lun there reminds readers of the book's relevance to the preceding series, and in fact is quite simply a tribute to the author.

Research on Sino-foreign exchanges of scientific and technological knowledge was planned from the founding of the IHNS. In June 1956, Zhongguo ziran kexue yu jishu shi yanjiu gongzuo shi'ernian yuanjing guihua cao'an 中國自然科學與技術史研究工作十二年 遠景規劃草案 (Draft of the twelve-year vision plan for research on the history of natural sciences and technology in China) already suggested that "research should be conducted regarding the history of Sino-foreign exchanges in science and technology" (应研究中国与其他国家的科技交流史) (Zhang 2017, 146). In 1958, 1958-1967 nian ziran kexueshi yanjiu fazhan gangyao (cao'an) 1958-1967 年自然科学史研究发展纲要（草案) (1958-1967 development outline of research on the history of natural sciences [draft]) also advocated research in the history of science and technology in other Asian countries and their scientific exchanges with China (Zhang 2017). However, due to limitations in research conditions during the subsequent decades, Chinese scholars were still striving to catch up with some foreign counterparts by the end of the 
twentieth century. Pan was one of those exerting his utmost endeavors.

A thousand-page magnum opus, Zhongwai kexue jishu jiaoliushi lun drew on Pan's output from different periods of his career, much of it compiled based on his earlier works. Thus, although some sections are outdated when judged by the latest research findings, readers can fruitfully approach it from the following two angles. First, by considering it as a summary of his academic work up to that time (such as Pan 1993; Pan 2002, etc.). Second, by viewing it as representative of explorations in the history of scientific exchanges among Pan's contemporaries, who were unable to fully devote themselves to research until the 1980s due to years of obstruction by political movements, especially the Cultural Revolution (1966-1976), rather than as presenting the cutting-edge of the latest research in the field in China.

The main body of the book comprises a total of fourteen chapters, encompassing almost all major categories of ancient science and technology. Chapters, and even sections in each chapter are not evenly distributed. The table of content is reminiscent of the weighty tomes of Joseph Needham. Similarly, Pan amalgamates mathematics and calendrical astronomy in a brief chapter, whereas the greater part of the book is equivalent to the categories in volumes 5 and 6 of Science and Civilisation in China. Evidently, this imbalance is the result of the chemistry background that Pan shared with Needham. In a recent interview, Pan noted that he was not a physics major, with little knowledge of magnetism, for instance, and he acknowledged the far-reaching impact of Needham (Huang et al. 2017).

The various chapters of the book are listed here in order of length:

1 Chapter 4 "Chemistry and Chemical Industry" is the longest (125 pages), and deals with gunpowder and firearms, lacquering, and alchemy.

2 Chapter 1 "General" explicates topics on the diffusion of Chinese science and technology in the Ming and Qing dynasties.

3 Chapter 13 "Figures" discusses the fifth-century scholar Wang Ren 王仁 (Wangin / Wani) and his contributions to Japanese learning, the role of Qing Emperor Kangxi in the transmission of Western science and technology to China, and Joseph Needham's research on these topics.

4 Chapter 7 "Medicine" dedicates a large part to elaborating on several Chinese medical experts who went to Japan after the seventeenth-century.

5 Chapter 9 "Printing" delves into the spread of block printing and movable-type printing.

6 Chapter 5 "Biology" not only studies the impact of ancient Chinese science on Darwin (published in Chinese Annals of History of Science and Technology) (Pan 2018), but also examines the outbound diffusion of knowledge on fauna and flora, such as goldfish, tea, and ginseng.

7 Chapter 10 "Metallurgy" centers on the transmission of smelting techniques 
of steel, brass, zinc, paktong, etc., and the introduction of De re metallica (Kunyu gezhi 坤與格致 [Investigations of the earth's interior]) into China.

8 Chapter 11 "Mechanical Engineering" focuses on two special mechanical innovations in ancient China, deep-well drilling and the double-acting piston blower.

9 Chapter 8 "Papermaking" describes the influence of Chinese papermaking techniques worldwide in ancient and early modern times, as well as noting pertinent materials in Honoré de Balzac's novels.

10 Chapter 6 "Agriculture" includes farm implements, silk, the crops from the Americas that spread from China to Korea, etc.

11 Chapter 3 "Physics" is concerned with the spread of the compass, thermometer, and hygrometer through East Asia.

12 Chapter 14 "Culture" includes the dissemination of chopsticks and Qianzi wen 千字文 (Thousand characters classic).

13\&14 Chapter 12 "Shipbuilding and Navigation" and Chapter 2 "Mathematics and Astronomy-Calendar" are very brief, with no more than twenty pages each.

With regard to specific research subjects, Pan primarily employs two kinds of narrative methods. On the one hand, a direct connection is made between the two sides involved in the communication, for instance, "Medical exchange between China and Arabia" and "Great Emperor Kangxi (K'anghsi) and Western science," though Pan does not include much recent research. This is not unusual in many other works highlighting contributions of pre-modern Chinese scientific attainments to contemporary and modern civilizations, but runs the risk of over-simplifying or violating the mechanisms of transmission. Nevertheless, Pan relies more on a second, quasi onion-layering, methodology. For a particular field of science and technology, Pan first documents its origin and development in China, and then makes a layer-by-layer analysis of exchanges from the center to the periphery in order of proximity to China. In the case of the transmission of Chinese papermaking techniques, for instance, Pan first describes the innermost layer encompassing East Asia, South Asia, and Southeast Asia, then expands outwards to Central Asia, West Asia, and North Africa, and finally to Europe, America, and Oceania. Such a narrative method unveils a stepped distribution of knowledge dissemination in terms of time, density, and probability.

Naturally, readers will compare this treatise with the hefty works of Joseph Needham. Clearly, the close friendship between Pan and Needham allowed them to share a multitude of sources, as indicated in the Islamic and European historical materials on science and technology cited by Pan, and in many relevant volumes of Needham's writings. There is also a plurality of chapters typical of Pan's personal style, including those on Chinese scientific works translated into Western languages in 
the Qing dynasty, the activities of Chinese scholars in Japan, historical materials in the novels of Balzac, and the impact of Chinese science and technology on Darwin. Other than these, Pan's discussions of knowledge dissemination in many scientific and technological categories are far from merely a condensation of information in Needham's monographs. The innermost layer of the Sino-foreign interactions of scientific knowledge, for example, involves scientific exchanges between China and such regions as Japan and Korea, the historical materials about which are rarely recorded or not touched upon at all in Science and Civilisation in China.

In his book, Pan also reveals an aspiration rare amongst scholars on the Chinese mainland accentuating the impact of Chinese science and technology on foreign countries. The requirement of mastering an abundance of overseas historical sources makes such studies more demanding than those concerning external influences on Chinese science and technology. Nevertheless, regardless of the secluded conditions under which scholars worked in the 1950s and 1960s, Pan doggedly acquired a reading knowledge of several academic languages, such as English, French, Russian, German, and Japanese, even becoming capable of making use of some Latin and Arabic texts. These skills underpin the foundations for Zhongwai kexue jishu jiaoliushi lun, and were uncommon for scholars of his age in China.

Researching the broad scope of the history of Sino-foreign exchanges of science and technology requires immense reserves of knowledge. Too much reliance on secondary sources that are not grounded in extensive research is likely to result in flawed conclusions. Such pitfalls compound the difficulties of boldly hypothesizing about the subject and scrupulously seeking out evidence, bravely confronted by scholars including Pan and Needham. Hence, flaws are unavoidable in Pan's encyclopedic work. One such example serves to illustrate this: Pan observes that The Canon of Medicine by Ibn Sina quotes Chinese pulse diagnosis, which was transmitted on to Europe. However, pulse diagnosis was common and most likely indigenous in origin in many ancient civilizations. Such traditions naturally resemble one another in some respects, and Chinese pulse diagnosis is just one variety of a form of knowledge with many sources. Currently, it remains difficult to identify the westward spread of Chinese pulse diagnosis before the Mongol empire.

The above-mentioned flaws simultaneously reveal another deficiency in Pan's work, that is, the lack of a theorical framework. The word "exchange" in the book's title is not defined. Pan does not apply theoretical tools such as transcultural diffusion models in his work. This shortcoming cannot be entirely ascribed to Pan, because it was difficult for him to acquire the academic sources he needed in his early career owing to the particular academic context before the 1980s.

Zhongwai kexue jishu jiaoliushi lun, like Pan's other monumental works, showcases the common inclination in the twentieth century to produce general history treatises. 
Distinctive from the team collaboration of Needham's Science and Civilisation in China and Zhongguo kexue jishu shi edited by Lu Jiaxi, Pan embodies more of his own efforts in his writings, which largely rely on historical texts, and differ strikingly from present-day research on the history of East-West scientific exchanges using scientific archaeology as the main means. There is no escaping the fact that texts are of fundamental significance for studies into cross-cultural transmission of science and technology, and further efforts are required in subsequent research to mesh the two methodologies. That said, the epic-length Zhongwai kexue jishu jiaoliushi lun is a must-read for the field.

\section{References}

Huang, Xing 黄兴, Li Ang 李昂, and Pan Jixing 潘吉星. 2017. “Ronghui Zhongxi hua keji guantong gujin cu yanjiu Pan Jixing xiansheng fangtan lu” 融会中西话科技 贯通古今促研究 - 一潘吉星先生访谈录 (An Interview with Pan Jixing). Guangxi minzu daxue xuebao (Ziran kexue ban) 广西民族大学学报（自然科学版） (Journal of Guangxi University for Nationalities [Natural Science Edition]) 23 (3): 1-9.

Pan, Jixing. 1993. Zhongwai kexue zhi jiaoliu 中外科學之交流 (Scientific exchange between China and foreign countries). Hong Kong: The Chinese University Press.

Pan, Jixing. 2002. Zhongguo gudai sida faming: Yuanliu waichuan ji shijie yingxiang 中国古代四大发 明：源流、外传及世界影响 (The Four Great Inventions of Ancient China: Their Origin, Development, Spread and Influence in the World). Hefei: University of Science and Technology of China Press.

Pan, Jixing. 2018. "A New Inquiry into the Chinese Sources Used by Charles Darwin." Chinese Annals of History of Science and Technology 2 (2): 19-40.

Zhang, Baichun 张柏春. 2017. “Bawo shidai maibo, kaituo xueshu xinjing: Zhongguo kexueyuan ziran kexueshi yanjiusuo 60 nian” 把握时代脉搏, 开拓学术新境: 中国科学院自然 科学史研究所 60 年 (Sixty Years of Development of the Institute for the History of Natural Sciences, Chinese Academy of Sciences: 1957-2016). Ziran kexueshi yanjiu 自然科学史研究 (Studies in the History of Natural Sciences) 36 (2): 143-151. 